\title{
School transportation program as means to improve public education in a minor rural town in Northeastern Brazil*
}

\author{
Maria Victória Leal de Almeida Nascimento ${ }^{a}$ \\ Mauricio Oliveira de Andrade ${ }^{b}$
}

\section{Abstract}

School transportation is crucial for access and permanence of students at school, in rural areas. The Brazilian government has funded school transport programs to support municipalities. This research aims to analyze if these programs are perceived as effective in small rural municipalities. Seeking this objective, a survey was carried out among students and teachers. Quantitative and qualitative analyses were conducted to test the results. In the quantitative analysis, it is observed that the majority of students are very pleased, being regularity/punctuality the bestevaluated criterion. Teachers believe punctuality has improved, school evasion has decreased, and school performance has increased. In a combined analysis, the evaluations carried out by teachers regarding school evasion and performance presents a significant relationship with regularity/punctuality assessed by students. In the qualitative analysis, a grouping of ideas highlighted comfort, safety, civility and punctuality as positive, while most-cited negative points were overcrowding, lack of organization and discomfort.

Keywords: School Performance. Rural School Transport. Transport Policies. Transport Assessment.

\section{Introduction}

In Brazil, the Federal Constitution highlights the right to Education as a guarantee of full citizenship (BRASIL, 1988). In turn, the Education Guidelines

\footnotetext{
* The authors are grateful for the collaboration of Coordenação de Aperfeiçoamento de Pessoal de Nível Superior

- Brasil (Capes) for the financial support. This study was financed in part by the Capes - Finance Code 001.

a Universidade Federal de Pernambuco, Recife, PE, Brasil.

b Universidade Federal de Pernambuco, Recife, PE, Brasil.
} 
and Bases Act (LDB) regulates the students' right to school-Teaching material, transportation, food, and health care (BRASIL, 1996). Public school students have also been granted the right to school transportation (BRASIL, 1988) and the Brazilian Transit Code - CTB (BRASIL, 1997) prohibits transporting students in unauthorized vehicles.

To ensure students have access to adequate school transportation, the National Fund for Education Development (FNDE) operates two programs: the National Support Program for School Transportation (PNATE) and the "School Path" Program. These programs aim to meet the needs of public school students to facilitate their access to Basic Education. Their intent is to cover expenses related to the acquisition and operation of school transportation vehicles, by means of financial assistance.

However, according to Carvalho et al. (2010), the mere existence of school transportation programs does not guarantee the service is adequately provided. Poor transport conditions are major barriers to the access and retention of students in schools. As a consequence, overcrowding and precarious conditions, such as lack of comfort and a high risk of accidents, result in long commute times and a probable decrease in learning performance.

In Brazil, two of the crucial educational problems are access and permanence at school. Transportation is crucial to ensure the students' attendance mainly in rural areas. To Lopes et al. (2020), there is a trend to rural students present lower school performance than urban students due to socioeconomic factors. Additionally, the lack or inadequate provision of school transportation services like overcrowding often adversely affect students' performance and contribute to early school leaving (CARVALHO et al., 2015; KOTOULA et al., 2017; MARTINS, 2010; SANTOS, 2010).

Brazil has continental dimensions; in all regions, there is a predominance of municipalities with less than 20 thousand inhabitants (IBGE, 2010), which correspond to almost $70 \%$ of Brazilian municipalities. This condition emphasizes school transport difficulties, mainly because there is a lack of studies that address mobility and accessibility problems focusing on educational outcomes.

Issues regarding students' access to schools in small municipalities or communities are certainly similar in many parts of the world. Developing countries, especially in their poorest regions, usually have much in common. 
Applying a method of analysis to a concrete typical case may be useful to propose or adjust public policies, which can be replicated in localities with similar characteristics.

Furthermore, it is important to highlight the role of rural school transportation to achieve some of United Nations (UN)'s interconnected Sustainable Development Goals (SDG) for 2030. The proposed goals aim eradication of poverty, quality Education and reduction of inequalities. The existence of sustainable and adequate means of transportation for rural students can help overcome poverty and its related problems, while improving well-being, access to quality education, gender equality, reduction of inequalities, among others (UN, 2015).

This research aims to analyze the effectiveness of federal programs of school transportation applied to minor Brazilian municipalities, using as an example, Santa Maria do Cambucá - PE, a typical municipality of less than 20 thousand inhabitants with almost 75\% living in rural areas (IBGE, 2010). The dispersed rural population is primarily supported by subsistence economic activities like agriculture, commerce, basic services, small-scale clothing industries and limestone mining. This town is situated in Northeastern Brazil, the most impoverished region of the country and characterizes one third of the municipalities in the region. As a case study, the results may be extended to similar municipalities, according to a naturalistic generalization.

For this, a survey was conducted among students and their teachers. With the students, the purpose was to verify their level of satisfaction with the transport they had been using. In order to analyze the effectiveness of these policies, the teachers responded to another survey, aimed at checking if the implemented transport services had been affecting the students' school performance.

This article also seeks to contribute to the literature on school rural transport in under developed regions, in issues such as: (i) negative and positive points of rural school transport, according to students' perception; ii) the effectiveness of rural school transport programs in teachers' understanding.

To support the research, a literature review was carried out focusing on transportation, social inclusion and school performance. The review has also been extended to cover issues related to public school transport policies. The following topics describe the methodology, results and discussions, and the conclusions of the study. 


\section{Literature review}

Social inclusion policies have the purpose of guaranteeing to the most disadvantaged the right of access to services such as education, health, work, and supplies. In addition, a strategy to combat social exclusion is to guarantee access to essential public services (RAHAMAN; RAHAMAN, 2009). Generally, demand and public transport needs are constantly increasing; therefore, transport authorities should be able to permanently supply better services, focusing on increasing passengers' safety and comfort as well as reducing commute times (BUCHEANU, 2018). In this context, limited access can result in a decrease of quality of life and wellbeing, while causing social exclusion (PYRIALAKOU et al., 2016).

School transport is crucial to society, as it facilitates access to education. Besides, it affects a sensitive age group, as highlighted by Sakellariou et al. (2017). Therefore, an appropriate planning and operation, emphasizing efficiency and safety, needs to be considered (CARVALHO et al., 2010). In addition, inefficient service provision may impact the right to public education, especially to children from low-income families. Furthermore, the problem is even worse in remote areas, unattended by public transport (KOTOULA et al., 2017).

Nevertheless, an international literature review conducted by Martins (2010) led to the conclusion that there is generally a small association between commute time in school transportation and students' academic results. Caiado and Gonçalves (2014), analyzing the availability and conditions of public school transportation for students with special educational needs (SEN) in São Paulo, concluded that precarious school transport conditions interfere with the students' access, attendance and permanence, especially among rural residents.

Several studies have been conducted in Brazil regarding the relationship between transport and school performance. Costa et al. (2014) in a study in 124 municipalities of Rio Grande do Norte, sought to find a relationship between indicators of school transportation programs and students' performance. Results show that, improved services have contributed to reduce school dropout, but the available data does not allow accepting the influence on increasing educational performance.

Still in Northeastern Brazil, Lopes et al. (2020) carried out a comparative study on school performance among students from urban and rural areas. The research pointed out that students who live in the countryside perform less. Some teachers believe that transport conditions represent a limiting factor for educational development. This is justified to students living in the countryside experience tiring and discouraging travels, in addition to reducing extra-class study time. The 
situation is even worse when vehicles and roads used are not in good conditions, increasing the risks for students.

In Anápolis - GO, Martins (2010) conducted a research aiming to assess the impacts of rural school transport conditions on the students' school performance. The study focused on commute times, distances, and conditions of vehicles and roads. She also investigated the teachers' opinions regarding school attendance, punctuality, and health indispositions caused by the school transport. The results showed no significant association between these criteria.

Santos (2010) identified the main problems of school transportation in a national survey in Brazil. The author observed that, in general, vehicles are inadequate, roads present poor maintenance conditions, and the available resources are insufficient. In turn, Carvalho et al. (2010), providing an overview on rural school transport in Brazil and analyzing its effects on educational performance, concluded that a number of factors lead to students feeling exhausted. These include overcrowding, long commute times, long distances, long waiting times, poor road conditions and poorly maintained vehicles.

Analyzing school transportation programs in Brazil, Cruz et al. (2010) emphasize they are still characterized by inefficient contractual practices, poor control, and lack of legal instruments to penalize inadequate services. As a result, this often leads to operators providing services according to their own interests. In addition, the service's remuneration is low, leading to the use of older vehicles, lack of safety equipment and inconvenient routes. Furthermore, Pergher (2014) highlights the limitations of local financial capacity and its great dependence on Union and State resources. However, the Federal Tribunal of Accounts (TCU, 2020) has verified the lack of an efficient and integrated management of school transport by FNDE and by state and municipal Education departments.

Pinheiro (2013) diagnosed rural school transport in Cachoeiro do Itampemirim ES through visits to schools and the application of questionnaires among students, parents, teachers and drivers. The survey showed that part of the interviewees was dissatisfied with some aspects of the service, especially seat comfort, temperature inside the vehicle, and vehicles' cleaning and maintenance.

Focusing on the subject of school transportation, Santos (2010) proposes a manual to support local governments. At first, he points out that students are subject to long journeys, long distances, irregular services, even using poorly maintained roads. In order to contribute to improving the quality of school transportation, state and 
municipal authorities should develop the necessary organizational, planning and regulatory skills. The results suggest the need to use a planning model in which policies are built with local social participation and support, while maintaining control of the process by the public authorities.

Summarizing the reviewed literature, we observe the importance of regularity and punctuality, since transport services were usually irregular and subject to delays (SANTOS, 2010). In addition, problems related to overcrowding (CARVALHO et al., 2010), seat comfort, environmental conditions, cleanliness, and vehicle conservation status were also highlighted (LOPES et al., 2020; PINHEIRO, 2013). Moreover, vehicle safety was evaluated as poor in some situations (CRUZ et al., 2010; SAKELLARIOU et al., 2017). For Cruz et al. (2010), Santos (2010) and Schuh et al. (2015), the routes are usually inadequate, often with poorly maintained roads. Besides, commute time is also important, as students are subject to long journeys over long distances (SANTOS, 2010; MARTINS, 2010). To obtain satisfactory results in school transport, the literature points out the importance of assessing regularity of operations, conditions of vehicles and quality of infrastructure and routes.

\section{Methodology}

To analyze the effectiveness of the federal programs supporting school transport in Brazil, both from the students and teachers 'perspectives, a survey was carried out in 2017 in Santa Maria do Cambucá, a typical small Brazilian municipality, adopted as a case study, located in the Northeast region, with a population estimated in 14,000 inhabitants in 2019 (IBGE, 2020).

After the implementation of the Federal Government programs, a survey was carried out among students who had been using the school transport, comparing the situation before and after. This survey considered influential factors extracted from the literature. In addition, another survey was carried out among the teachers to evaluate if the program implementation generated benefits to the students' school performance. For a better understanding of the methodological steps adopted, Figure 1 shows a flowchart of the research development.

A survey with students and teachers was carried out by applying questionnaires in schools. Students and teachers from a random sample of 15 out of 26 state and municipal public schools were interviewed. 385 students were surveyed by proportional random sampling and stratified by grade and gender, seeking to reach a $95 \%$ confidence level and a 5\% margin of error. As 22 surveyed students did not use school transport previously, 363 responses were validated, increasing the margin of sampling error to $5.14 \%$. The sampling of teachers was 
for convenience, but it covered all 15 schools where students were interviewed. 32 teachers participated representing $25 \%$ of the total.

Figure 1 - Research Flowchart

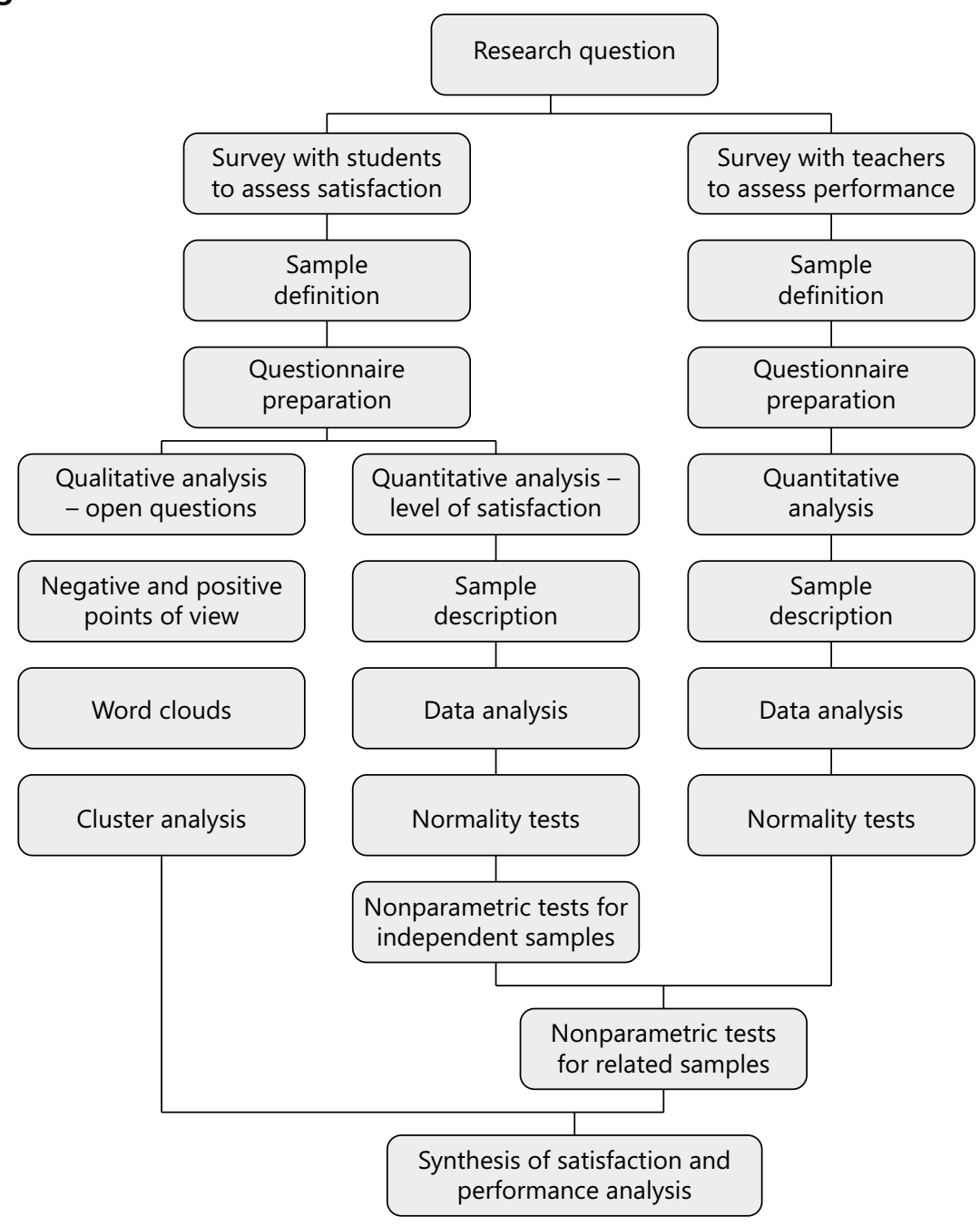

Source: Authors (2020)

First, the questionnaire applied among the students identified gender, age, level of schooling, place of residence, location of school, means of transportation, and the 
type of road in the route. Additionally, the questionnaire included the assessment of some important quality factors in transport studies: regularity/punctuality, comfort, safety, commute time and route (ANDRONICEANU, 2016; BUCHEANU, 2018; CAIADO; GONÇALVES, 2014; CARVALHO et al., 2010; SCHUH et al., 2015).

The students' ratings about their satisfaction level with the school transport were based on a Likert scale: 1 (very dissatisfied), 2 (dissatisfied), 3 (indifferent), 4 (satisfied) and 5 (very satisfied). The assessment in five levels is due to its greater comprehensibility when interviewing students from early grades. In the end, through open-ended questions, students were asked about the main positive and negative aspects of the transport currently used.

In another questionnaire, the teachers were asked about gender, level of schooling, time as a teacher, and time working at the current school. In sequence, also through a Likert-type scale, they revealed their level of agreement with three statements based on the reviewed literature (CAIADO; GONÇALVES, 2014; CARVALHO et al., 2010; COSTA et al., 2014; MARTINS, 2010). The statements were: "The implementation of school transportation programs: i) has contributed to reduce school dropout; ii) has contributed to raise students' average school performance (grades); and iii) has contributed to increase the students' punctuality and attendance". Possible responses were: 1 (totally disagree), 2 (partially disagree), 3 (neither agree nor disagree), 4 (partially agree) and 5 (totally agree). For comparative purposes, a Likert-type scale with 5 levels was used.

The answers were submitted to quantitative and qualitative analysis to achieve a combined interpretation of the results. In the quantitative analysis, KolmogorovSmirnov normality test, nonparametric tests for independent samples (KruskalWallis) and related samples (Friedman test) were applied.

On the other hand, a qualitative analysis of the students' open answers was conducted through a text mining technique, with outputs in clouds with the most relevant ideas. Text mining is a process of extracting relevant information from text databases (PEZZINI, 2016). One of the techniques used in text mining is clustering, a step in which data is separated into clusters and aspects with similar attributes belong to the same cluster, whereas aspects with dissonant attributes belong to distinct clusters.

Additionally, the perceived intrinsic characteristics or similarities of the responses were revealed using cluster analysis, which is a formal study of methods and algorithms for grouping objects (JAIN, 2010). In this case, the profile of the 
respondents is tested by the frequency in which their ideas were mentioned, from positive and negative points. The groupings reveal the affinities and differences between the various students' profiles and commute characteristics. K-means histograms grouping were the outputs for this analysis.

\section{Results and discussions}

As proposed in the methodology, firstly the quantitative analysis presents the profile and evaluation of students and teachers, as well as the relationship between these assessments. Secondly, a qualitative analysis is performed, with the interpretation of the students' open answers regarding the positive and negative aspects of school transportation. This qualitative analysis is confronted with the results from the quantitative analysis, to finally extract the synthesis of the study.

\subsection{Sample profile and evaluation by students}

Initially, Table 1 shows a descriptive analysis of the students' sample profile.

Table 1 - Students profile

\begin{tabular}{lccc}
\hline Description & Classification & Quantity & Percentage \\
\hline \multirow{2}{*}{ Gender } & Female & 186 & 51.24 \\
& Male & 177 & 48.76 \\
\hline \multirow{2}{*}{ Level of schooling } & Preschool & 45 & 12.40 \\
& Elementary School & 282 & 77.68 \\
& High School & 36 & 9.92 \\
\hline \multirow{2}{*}{ Age } & $0-9$ & 137 & 37.74 \\
& $10-19$ & 223 & 61.43 \\
& $20-29$ & 2 & 0.55 \\
Place of residence & $30-39$ & 1 & 0.28 \\
\hline \multirow{2}{*}{ School location } & Urban & 16 & 4.41 \\
& Rural & 347 & 95.59 \\
\hline \multirow{2}{*}{ Means of } & Urban & 239 & 65.84 \\
transport & Rural & 124 & 34.16 \\
\hline Type of road & Bus & 339 & 93.39 \\
surface & Minibus & 13 & 3.58 \\
\hline Source: Autholkswagen Kombi van & 11 & 3.03 \\
\hline
\end{tabular}

Source: Authors (2020) 
In the sample, there is a subtle female predominance (51.24\%). Regarding the Education level, the majority of students attend elementary school (77.68\%), since it is where most classes are. Most respondents are aged from 10 to 19 years $(61.43 \%)$, followed by those aged 0 to $9(37.74 \%)$, representing together more than $99 \%$ of the interviewees. The vast majority of interviewees live in rural areas $(95.59 \%)$, although most of them attend schools located at nearby urban centers $(65.84 \%)$. Regarding means of transportation, buses are the most used $(93.39 \%)$. Finally, the roads taken in the students' commute to school are mostly unpaved (65.29\%).

Regarding all answers, it is possible to conclude that most students are very pleased with the transport service in all proposed criteria (mode $=5$ in the Likert scale) comparing to the previous situation. However, observing the mean, it is possible to capture subtle differences. The best accepted criterion is regularity/ punctuality $($ mean $=4.57)$, followed by time $($ mean $=4.38)$, route $($ mean $=4.37)$ and comfort (mean $=4.11)$. Finally, safety, despite revealing a certain level of satisfaction, presents the lowest mean (4.07) and median (4) values.

The Kolmogorov-Smirnov test was applied to verify if the results are normally distributed. It is possible to conclude that the answers' distribution for each criterion does not configure a normal distribution. Therefore, applying non-parametric tests was the alternative to proceed.

In its turn, the non-parametric Kruskal-Wallis test for independent samples was used, seeking to identify if the students' characteristics and travel data lead to different perceptions of transport quality. In order to evaluate whether the distribution of the results is the same among all the categories studied, the test should seek significance greater than $5 \%$.

Starting with the students' gender, the answers for all criteria are the same for regularity/punctuality $($ significance $=0.668)$, comfort $($ significance $=0.953)$, safety $($ significance $=0.763)$, time $($ significance $=0.425)$ and route (significance $=0.301)$. This means gender does not interfere in the assessment.

Regarding means of transportation, some criteria have presented statistically different results. The criteria regularity/punctuality ( significance $=0.068$ ), time (significance $=0.283$ ) and route (significance $=0.172$ ) demonstrate the same evaluation among the means of transport available. Thus, the means of transport does not interfere in the evaluation of regularity/punctuality, commute time, nor the route used. The results for comfort (significance $=0.005$ ) and safety 
(significance $=0.002)$ are not distributed in the same way. In other words, more compact vehicles like Volkswagen Kombi Vans in terms of comfort and safety present a lower evaluation level, as demonstrated in Table 2 .

Table 2 - Means, medians and modes for means of transport in students' evaluations

\begin{tabular}{lcccccc}
\hline & & $\begin{array}{c}\text { Regularity/ } \\
\text { punctuality }\end{array}$ & Comfort & Safety & Time & Route \\
\hline \multirow{3}{*}{ Bus } & Mean & 4.55 & 4.10 & 4.07 & 4.37 & 4.35 \\
& Median & 5.00 & 5.00 & 4.00 & 5.00 & 5.00 \\
& Mode & 5.00 & 5.00 & 5.00 & 5.00 & 5.00 \\
\hline \multirow{3}{*}{ Minibus } & Mean & 4.69 & 4.92 & 4.77 & 4.77 & 4.85 \\
& Median & 5.00 & 5.00 & 5.00 & 5.00 & 5.00 \\
& Mode & 5.00 & 5.00 & 5.00 & 5.00 & 5.00 \\
Volkswagen & Mean & 5.00 & 3.64 & 3.36 & 4.36 & 4.36 \\
Kombi van & Median & 5.00 & 4.00 & 3.00 & 4.00 & 4.00 \\
& Mode & 5.00 & 3.00 & 3.00 & 4.00 & 4.00 \\
\hline
\end{tabular}

Source: Authors (2020)

The satisfaction with regularity/punctuality is independent from the road surface, as it has the same median and mode (5.00) and close means (4.50 to 4.66). However, all other criteria, such as comfort (significance $=0.000$ ), safety ( significance $=$ 0.000 ), time ( significance $=0.023$ ) and route (significance $=0.005$ ), depend on the type of road. Although having the same medians and modes (5.00) the means differ. Safety is the lowest assessed criteria.

School location interferes in the evaluation of all the analyzed criteria, since the tests present significance less than 5\%. Although the mode is the same, the median and especially the mean diverge between rural and urban. Table 3 shows these numbers, indicating that the students' assessment depends on the location of the school.

As for the place of residence, the only criterion that interferes in the assessments is route quality (significance $=0.035$ ). In contrast, the other criteria show the same distribution, with significance over 5\%. That is, the evaluations of regularity/ punctuality, comfort, safety and time are independent from the site of residence. Table 3 shows that, despite the same medians and modes in most criteria, the mean for the route differs. 
Table 3 - Means, medians and modes for school and residence in students' evaluations

\begin{tabular}{lcccccc}
\hline & & $\begin{array}{c}\text { Regularity/ } \\
\text { punctuality }\end{array}$ & Comfort & Safety & Time & Route \\
\hline \multirow{2}{*}{$\begin{array}{l}\text { Rural } \\
\text { School }\end{array}$} & Mean & 4.84 & 4.81 & 4.41 & 4.61 & 4.65 \\
& Median & 5.00 & 5.00 & 5.00 & 5.00 & 5.00 \\
& Mode & 5.00 & 5.00 & 5.00 & 5.00 & 5.00 \\
\hline \multirow{2}{*}{ Urban } & Mean & 4.43 & 3.76 & 3.90 & 4.26 & 4.22 \\
School & Median & 5.00 & 4.00 & 4.00 & 5.00 & 5.00 \\
& Mode & 5.00 & 5.00 & 5.00 & 5.00 & 5.00 \\
\hline \multirow{2}{*}{ Rural } & Mean & 4.59 & 4.14 & 4.08 & 4.36 & 4.35 \\
residents & Median & 5.00 & 5.00 & 4.00 & 5.00 & 5.00 \\
& Mode & 5.00 & 5.00 & 5.00 & 5.00 & 5.00 \\
\hline \multirow{2}{*}{ Urban } & Mean & 4.25 & 3.75 & 3.81 & 4.81 & 4.88 \\
residents & Median & 4.00 & 4.00 & 4.00 & 5.00 & 5.00 \\
& Mode & 5.00 & 4.00 & 5.00 & 5.00 & 5.00 \\
\hline
\end{tabular}

Source: Authors (2020)

The schooling level interferes in the evaluation of all the criteria. According to Table 4, means, medians and modes diverge according to the students' level of schooling. High school students are more rigorous, assigning lower mean scores for all the criteria. In addition, the median and modes are lower for most criteria.

Table 4 - Means, medians and modes for schooling level in students' evaluations

\begin{tabular}{lcccccc}
\hline & & $\begin{array}{c}\text { Regularity/ } \\
\text { punctuality }\end{array}$ & Comfort & Safety & Time & Route \\
\hline \multirow{2}{*}{ Child } & Mean & 4.96 & 4.69 & 4.00 & 4.51 & 4.51 \\
Education & Median & 5.00 & 5.00 & 4.00 & 5.00 & 5.00 \\
& Mode & 5.00 & 5.00 & 4.00 & 5.00 & 5.00 \\
\hline \multirow{2}{*}{ Elementary } & Mean & 4.51 & 4.17 & 4.18 & 4.43 & 4.45 \\
School & Median & 5.00 & 5.00 & 5.00 & 5.00 & 5.00 \\
& Mode & 5.00 & 5.00 & 5.00 & 5.00 & 5.00 \\
\hline \multirow{3}{*}{ High School } & Mean & 4.53 & 2.97 & 3.33 & 3.83 & 3.53 \\
& Median & 5.00 & 3.00 & 3.00 & 4.00 & 4.00 \\
& Mode & 5.00 & 3.00 & 3.00 & 4.00 & 5.00 \\
\hline
\end{tabular}

Source: Authors (2020)

Analyzing the relationships between students' profiles and the satisfaction levels based on the journeys' characteristics, most of them show no differentiation. 
However, there are different situations that need to be explained. Depending on the means of transport used, the interviewees demonstrated different levels of satisfaction in aspects as comfort and safety. The type of road interferes in the satisfaction regarding comfort, safety, commute time and route. School location is relevant and influences the evaluation in all criteria. The zone of residence interferes only with the assessment of the route to school. Finally, the students' schooling level interferes in the evaluation of all criteria.

The students' assessment results ensure that the provided school transport programs have been generally satisfactory. As such, from the students' point of view, the school transportation programs are fulfilling their role effectively.

\subsection{Sample profile and teachers' evaluation}

Table 5 describes the sample of teachers who participated in the survey.

Table 5 - Teachers' profiles

\begin{tabular}{lccc}
\hline Description & Classification & Number & Percentage \\
\hline \multirow{2}{*}{ Gender } & Female & 28 & 87.50 \\
& Male & 4 & 12.50 \\
\hline \multirow{3}{*}{ Graduation level } & High school & 1 & 3.13 \\
& Under graduated & 5 & 15.63 \\
& Graduated & 26 & 81.25 \\
\hline \multirow{3}{*}{ Years as a teacher } & $0-9$ & 1 & 3.13 \\
& $10-19$ & 10 & 31.25 \\
& $20-29$ & 17 & 53.13 \\
& $30-39$ & 3 & 9.38 \\
& $40-49$ & 1 & 3.13 \\
Years working at & $0-9$ & 18 & 56.25 \\
the school & $10-19$ & 9 & 28.13 \\
& $20-29$ & 5 & 15.63 \\
& $30-39$ & 0 & 0.00 \\
\hline
\end{tabular}

Source: Authors (2020)

After the initial characterization, the level of agreement with the proposed statements was tested. Punctuality/assiduity and school dropout reduction obtained medians and modes with maximum scores (5.00). The means are also very similar, 
with punctuality/assiduity being slightly higher. As a conclusion, it is clear the teachers believe that punctuality/assiduity has improved and the school dropout has diminished due to the school transport programs. However, the students' performances, despite the high scores, show a less positive evaluation (mean = 4.40 ; median $=$ mode $=4.00$ ).

Based on these results, it is possible to say that, in light of the teachers' opinions, the policy of school transportation has reached its objectives. To synthesize the results, the next step was to verify the correlation between the students' satisfaction assessments and the practical policy results perceived by the teachers.

\subsection{Combined analysis}

After the isolated analyses of both surveys, Friedman's non-parametric test for related samples was carried out to verify if the teachers' understandings followed the same distribution of the students' evaluations. To confirm the relationship between the criteria, the test significance must be higher than $5 \%$.

All possible interactions among the criteria were tested, and only two interactions proved a relationship between the criteria. The factor regularity/punctuality, assessed by the students, presented the same distribution of school evasion $($ significance $=0.071)$ and school performance $($ significance $=0.439)$. That means the teachers' evaluations of school evasion and performance have a significant relationship with the regularity/punctuality revealed by students.

The evaluation of school dropout presents the same mode and median of regularity/ punctuality, as well as a similar means. In the evaluation of school performance, the mean is also close to the obtained in the criterion regularity/punctuality revealed by students. From this test, it is possible to infer that students satisfied with the transport system may attend school more regularly and punctually, with a tendency to lower school dropout and better performance, as highlighted by Caiado and Gonçalves (2014) and Martins (2010).

\subsection{Qualitative analyses}

In addition to the students' evaluation of some important criteria regarding the current school transport, two open questions were proposed, eliciting the main positive and negative aspects of the transportation provided by the government programs. The students' responses were analyzed by the software Orange 3.16, using a text mining technique. After processing the textual information of the responses, a word cloud (Figure 2) highlighted the main ideas on the positive aspects mentioned. 
Figure 2 - Main positive aspects mentioned

\section{rapidity safety route \\ comfort \\ punctuality civility}

administration

Source: Authors (2020)

The main positive aspects highlighted are comfort, safety, civility, and punctuality. The federal programs promoted the renewal of the vehicle fleet. As a consequence, the students pointed out comfort and safety as new features when comparing to the previous situation. Regarding civility, the students expressed that the drivers are more attentive, careful and committed, providing well-being and improving punctuality.

Based on the students' ideas, a technique of non-hierarchical clustering by a k-means algorithm was applied to demonstrate the differences and affinities of opinion among groups of students. According to Jain (2010), the objective of a cluster analysis is to discover a natural set of patterns, points of view and objects, to define whether the individuals belong to distinct groups by comparing multiple characteristics. The histogram of Figure 3 expresses these groupings and its differences in opinion.

Figure 3 - Histogram of positive aspects by cluster

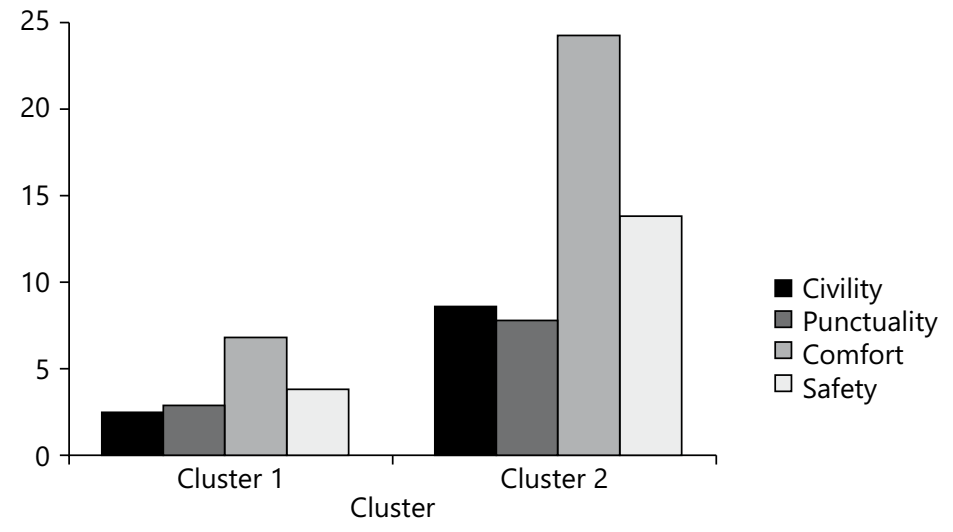

Source: Authors (2020) 
The histogram of Figure 3 was partitioned into two clusters focused on the positive aspects. The components of cluster 1, in spite of being generally satisfied, express fewer positive points. They are mainly urban residents (probably less impacted), high school students (more critical), attend rural schools (more difficult access), use compact vehicles and make trips longer than 30 minutes (two factors that generate discomfort). Cluster 2 represents the students with the highest level of satisfaction. These are predominantly elementary students, live in the countryside, attend urban schools, use buses, and their trips last up to 30 minutes. It is possible to conclude that, in the previous situation, students from rural areas were the most affected by the precariousness or absence of school transportation. Even when using better vehicles, longer commute times normally tend to reduce the satisfaction of users.

On the other hand, the main negative aspects are shown in Figure 4, where they form a word cloud generated by a hierarchical clustering technique.

Figure 4 - Main negative aspects mentioned

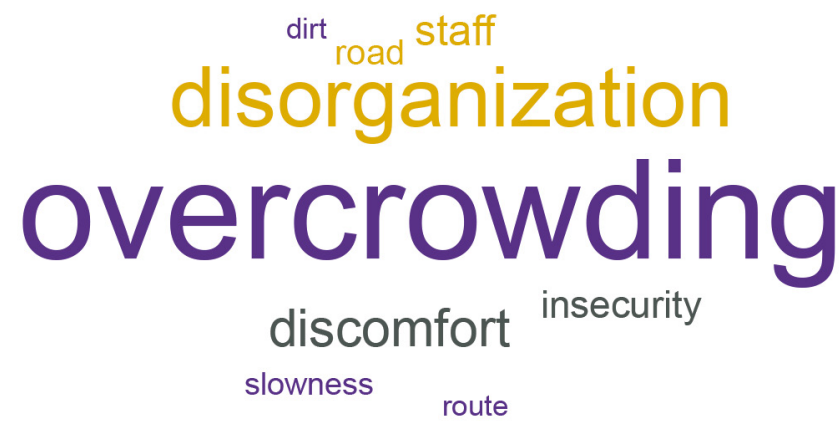

Source: Authors (2020)

Among the negative aspects, overcrowding was presented as the key problem, while disorganization and discomfort came next. Several witnesses have reported children traveling standing on buses and students without using seat belts disobeying the Brazilian Traffic Code-CTB (BRASIL, 1997). This happens due to lack of supervision by school and transportation authorities. Perhaps because of overcrowding, the interior of the vehicles seemed disorganized, leading many of them to feel uncomfortable. When comparing the main positive and negative aspects, a certain apparent contradiction is revealed, as overcrowding is, to some extent, incompatible with comfort.

The histogram of Figure 5 expresses the groupings and its differences in opinion intensity. The clusters 1 and 2 have the same profile of respondents revealed in 
the positive aspects' analysis. They express the same hierarchy of problems, but with different intensities. Cluster 2, although being more satisfied with the positive aspects, presented more critical aspects.

Figure $\mathbf{5}$ - Histogram of negative aspects by cluster

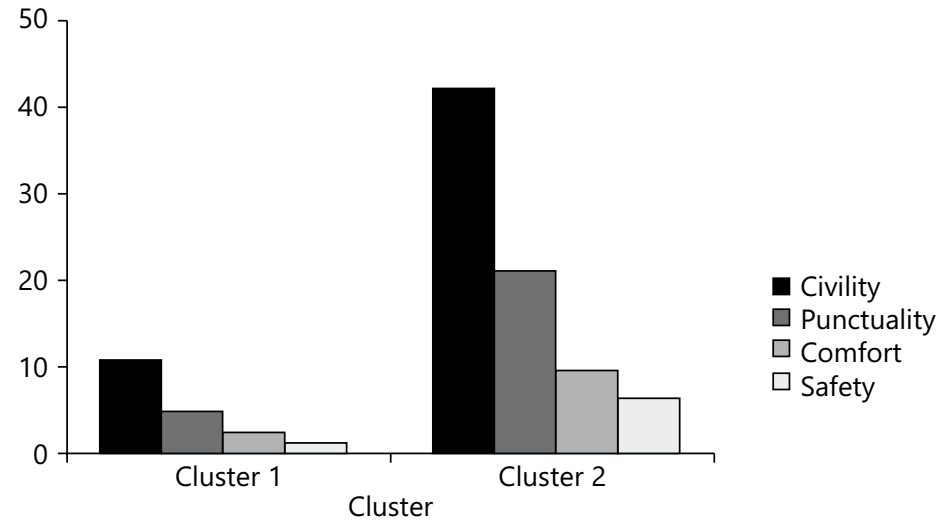

Source: Authors (2020)

As a summary of the qualitative results, users in general seem satisfied with the level of comfort, safety, civility and punctuality provided by the programs, proving that the school transport policy has been effective. These satisfaction criteria corroborate with the results reported in studies from Androniceanu (2016), Bucheanu (2018) and Sakellariou et al. (2017). However, the negative aspects pointed out some problems still need to be overcome. Overcrowding, disorganization and discomfort also appear as problems in the studies carried out by Carvalho et al. (2010), Pinheiro (2013) and Santos (2010).

Rural residents, students in urban schools and bus users are the most satisfied. However, students with the same features have expressed more negative points. Besides, students from elementary schools who make trips longer than 30 minutes have revealed a certain disappointment.

\section{Discussions}

In the quantitative analysis, all criteria received positive evaluations, being safety the lowest when compared with regularity / punctuality, time, route, and comfort. In the qualitative analysis, these same variables were presented as positive, as follows: comfort, safety, punctuality, agility, and itinerary. Despite this, some 
students complain about overcrowding, lack of comfort, insecurity, long itineraries, inadequately maintained roads and slowness. These results corroborate the findings of studies by Carvalho et al. (2010) about overcrowding, by Cruz et al. (2010) and Sakellariou et al. (2017), who highlight safety as a negative point; from Pinheiro (2013) who shows dissatisfaction with comfort; and Santos (2010) who points out that students are subjected to irregular and delayed transport services. As recommendations common to Bucheanu's research (2018), they suggest increasing safety and comfort to passengers in addition to reducing travel times. It is essential to improve planning and management of transport services (CARVALHO et al., 2010; CRUZ et al., 2010; PINHEIRO, 2013).

In opposition to the results obtained by Caiado and Gonçalves (2014), students residing in the countryside, attending urban schools and travelling by bus, comprise the ones who reported the most positive points. Despite in the survey by Lopes et al. (2020), the rural students presented lower school performance. However, this same group also reported negative points. This may be justified as even representing the vastest group, they present more diverse opinions. In the qualitative analysis, elementary school students are also dissatisfied, while in the quantitative, the most dissatisfied are high school students. It is also observed comparing the positive and negative points that the students perceive the services require a more efficient organization. The lack of order appears strong as a negative point and the organization appears very timid as a desirable attribute. With this same focus, Kotoula et al. (2017) report that planning emphasizing efficiency and safety needs to be considered.

However, the results based on the teachers' opinions accepting the hypothesis of a positive relationship between improved transport and school performance do not align with the conclusions of Costa et al. (2014) and Martins (2010). These authors state that the available data based on small samples in limited periods applying regression models are not enough to accept the causality of transport improving educational performance.

Finally, the results of the cluster analysis demonstrate the importance of differentiating the profiles of the most dissatisfied students and justify the need to better focus policies alleviate the problems revealed. In this way, it is possible to prioritize the groups most negatively affected, as the students, mainly of elementary classes that use compact vehicles and make longer journeys.

\section{Conclusions}

This article seeks to assess the perception of students of public schools in a small municipality of rural predominance on the school transportation quality after 
the implementation of the programs "School Path" and PNATE. We also seek to understand from the teachers' opinions, if they relate school transportation improvements with students' punctuality and attendance, school dropout reduction and improvement in students' performance.

In general, results point out that the students approve the new transport services; despite in some aspects they still demonstrate some dissatisfaction. The teachers reveal a positive perception of the considered aspects, despite with less emphasis on the improvement of the students' performance. The positive evaluations of improvements in regularity and punctuality of the transport services by the students are associated to the assessment of the teachers on improvement of assiduity and dropout reduction, allowing the conclusion of the achievement of the policy's basic results.

These results also contribute to the achievement of some UN's sustainable development goals: SDG-4 - Quality education, target 4.1 - ensure that all children and young people complete elementary and high school Education equitable and of high quality; and SDG-10 - Reduce inequality, target 10.3 - ensure equality of opportunities and reduce inequality of outputs (UN, 2015).

However, the lack of organization of the services still emerges to the students as a relevant problem (new and more comfortable vehicles are not enough), therefore, an efficient planning and operation is necessary. Thus, the reported problems of overcrowding which violate the traffic code for transporting students over capacity and without using seat belts should be minimized. More efficiency in the planning, regulation, inspection and management of the services by transit, transportation and school authorities, as recommended by Carvalho et al. (2010) and TCU (2020), and with support and participation of local stakeholders (SANTOS, 2010; MARTINS; 2010), would face this problem.

It is also highlighted the importance to ensure efficiency and accountability in the use of programs' resources and also, ensuring to students, safety when traveling, respecting existing rules and regulations.

As the type of road used in the transport influences the students' satisfaction with comfort, safety and travel time it is necessary that the municipalities with the support of the state government improve the maintenance of unpaved roads in all periods of the year, therefore corroborating with the recommendations of Cruz et al. (2010) and Santos (2010). 
As a case study, the findings may allow the development of a naturalistic generalization, in which, readers recognizing similarities in some results, may interpret them as comparative insights and intuitively combine with previous experiences. For future research, we suggest testing this methodology adapted to local conditions on typical small municipalities from other Brazilian regions, with different socioeconomic and infrastructural characteristics, trying to understand regional and local peculiarities. This could lead to a broader interpretation of the studied phenomenon. 


\section{Programa de transporte escolar como meio para melhorar a educação pública em um pequeno município rural no Nordeste do Brasil}

\section{Resumo}

O transporte escolar é fundamental para o acesso e a permanência dos alunos na escola, no meio rural. O governo brasileiro financiou programas de transporte escolar para apoiar os municípios. Essa pesquisa tem como objetivo analisar se esses programas são percebidos como eficazes em pequenos municipios rurais. Visando a esse objetivo, foi realizada uma pesquisa com alunos e professores. Análises quantitativas e qualitativas foram realizadas para testar os resultados. Na análise quantitativa, observou-se que a maioria dos alunos está muito satisfeita, sendo regularidade/pontualidade o critério mais bem avaliado. Os professores acreditam que a pontualidade melhorou, a evasão escolar diminuiu e o desempenho escolar aumentou. Numa análise conjunta, as avaliações realizadas pelos professores quanto à evasão escolar e ao desempenho apresentam uma relação significativa com a regularidade/ pontualidade avaliada pelos alunos. Na análise qualitativa, um agrupamento de ideias destacou conforto, segurança, civilidade e pontualidade como positivos, enquanto os pontos negativos mais citados foram superlotação, falta de organização e desconforto.

Palavras-chave: Desempenho Escolar. Transporte Escolar Rural. Politicas de Transporte. Avaliação de Transporte.

\section{Programa de transporte escolar como medio a mejorar la educación pública en un pequeño municipio rural del Noreste de Brasil}

\section{Resumen}

El transporte escolar es fundamental para el acceso y la permanencia de los estudiantes en la escuela, en las zonas rurales. El gobierno brasileño ha financiado programas de transporte escolar para apoyar a los municipios. Esta investigación tiene como objetivo analizar si estos programas se perciben como efectivos en pequeños municipios rurales. Con este objetivo, se realizó una encuesta entre estudiantes y profesores. Se realizaron análisis cuantitativos y cualitativos para probar los resultados. En el análisis cuantitativo, se observa que la mayoría de los estudiantes están muy satisfechos, siendo la regularidad/ puntualidad el criterio mejor evaluado. Los maestros creen que la puntualidad ha mejorado, la evasión escolar ha disminuido y el rendimiento escolar ha aumentado. En un análisis combinado, las evaluaciones realizadas por los docentes sobre la evasión y el desempeño escolar presentan una relación significativa con la regularidad/puntualidad evaluada por los estudiantes. En el análisis cualitativo, una agrupación de ideas destacó la comodidad, la seguridad, la cortesía y la puntualidad como positivas, mientras que los puntos negativos más citados fueron el hacinamiento, la falta de organización y el malestar.

Palabras clave: Desempeño Escolar. Transporte Escolar Rural. Políticas de Transporte. Evaluación del Transporte. 


\section{References}

ANDRONICEANU, A. The quality of the urban transport in Bucharest and how to improve it in accordance with the expectations of the citizens. Theoretical and Empirical Researches in Urban Management, Bucharest, v. 11, n. 1, p. 5-18, Feb. 2016.

BRASIL. Senado Federal. Constituição da República Federativa do Brasil de 1988. Brasília, DF, 1988.

BRASIL. Lei no 9.394, de 20 de dezembro de 1996. Estabelece as diretrizes e bases da educação nacional. Diário Oficial da União, Brasília, DF, 1996 Dec. 23.

BRASIL. Lei no 9.503, de 23 de setembro de 1997. Institui o código de trânsito brasileiro. Diário Oficial da União, Brasília, DF, 1997 Sept. 25.

BUCHEANU, A. M. Comparative analysis on public transport systems in european capitals: Bucharest \& Berlin. Theoretical and Empirical Researches in Urban Management, Bucharest, v. 13, n. 2, p. 65-75, May 2018.

CAIADO, K. R. M.; GONÇALVES, T. G. G. L. O transporte escolar público para alunos do campo com necessidades educacionais especiais. Teoria e Prática da Educação, Maringá, v. 17, n. 1, p. 119-130, Jan./Apr. 2014. https://doi.org/10.4025/tpe.v17i1.27725

CARVALHO, W. L. et al. Rural school transportation in emerging countries: the brazilian case. Research in Transportation Economics, Amsterdam, v. 29, n. 1, p. 401-409, 2010. https://doi.org/10.1016/j.retrec.2010.07.051

CARVALHO, W. L.; LEITE, P. S.; NASCIMENTO, H. P. Evolução do transporte escolar rural brasileiro no modo rodoviário. In: CONGRESSO NACIONAL DE PESQUISA EM TRANSPORTE, 29., 2015, Ouro Preto. Anais[...]. Rio de Janeiro: Associação Nacional de Pesquisa e Ensino em Transportes, 2015.

COSTA, R. R. A. et al. Transporte escolar rural: um estudo estratégico sobre a influência dos indicadores de qualidade na educação no ensino fundamental no RN. In: ENCONTRO DO ANPAD, 38., 2014, Rio de Janeiro. Anais[...]. Rio de Janeiro: Associação Nacional de Pós-Graduação e Pesquisa em Administração, 2014.

CRUZ, R. O. M. et al. Outsourcing rural school transportation: a brazilian handbook for practice at the municipal level. Research in Transportation Economics, Amsterdam, v. 29, n. 1, p. 312-318, 2010. https://doi.org/10.1016/j.retrec.2010.07.039 


\section{INSTITUTO BRASILEIRO DE GEOGRAFIA E ESTATÍSTICA}

- IBGE. Censo demográfico. Brasília, DF, 2010. Available from:

http://www.ibge.gov.br/home/estatistica/populacao/censo2010/default.shtm.

Access in: 2019 Mar. 16.

INSTITUTO BRASILEIRO DE GEOGRAFIA E ESTATÍSTICA - IBGE. IBGE cidades panorama: Santa Maria do Cambucá. Brasília, DF, 2020.

Available from: https://cidades.ibge.gov.br/brasil/pe/santa-maria-do-cambuca/ panorama. Access in: 2020 Apr. 27.

JAIN, A. K. Data clustering: 50 years beyond K-means. Pattern Recognition Letters, Amsterdam, v. 31, n. 8, p. 651-666, June 2010. https://doi.org/10.1016/j.patrec.2009.09.011

KOTOULA, K. et al. The existing school transportation framework in Greece: barriers and problems comparing to other european countries. Transportation Research Procedia, Amsterdam, v. 24, p. 385-392, 2017. https://doi.org/10.1016/j.trpro.2017.05.096

LOPES, S. G.; XAVIER, I. M. C.; SILVA, A. L. S. Rendimento escolar: um estudo comparativo entre alunos da área urbana e da área rural em uma escola pública do Piauí. Ensaio: Avaliação e Políticas Públicas em Educação, Rio de Janeiro, v. 28, n. 109, p. 962-981, Oct./Dec. 2020. https://doi.org/10.1590/s0104-40362020002802371

MARTINS, A.P. A. Análise dos impactos das condições do transporte escolar rural no rendimento escolar dos alunos. Dissertação (Mestrado em Transportes Urbanos) - Faculdade de Tecnologia, Universidade de Brasília, Brasília, DF, 2010.

PERGHER, C. J. Politica de transporte escolar rural no Rio Grande do Sul: configuração de competências e de relações (inter) governamentais na oferta e no financiamento. Tese (Doutorado em Educação) - Faculdade de Educação, Universidade Federal do Rio Grande do Sul, Porto Alegre, RS, 2014.

PEZZINI, A. Mineração de textos: conceito, processo e aplicações. Revista Eletrônica do Alto Vale do Irajaí, Ibirama, v. 5, n. 8, p. 1-13, Dec. 2016. https://doi.org/10.5965/2316419005082016058

PINHEIRO, T. G. B. S. Diagnóstico do transporte escolar rural público no município de Cachoeiro de Itapemirim - ES. Dissertação (Mestrado em Gestão Pública) - Centro de Ciências Jurídicas e Econômicas, Universidade Federal do Espírito Santo, Vitória, ES, 2013. 
PYRIALAKOU, V. D.; GKRITZA, K.; FRICKER, J. D. Accessibility, mobility, and realized travel behavior: assessing transport disadvantage from a policy perspective. Journal of Transport Geography, Amsterdam, v. 51, p. 252-269, Feb. 2016. https://doi.org/10.1016/j.jtrangeo.2016.02.001

RAHAMAN, K. R.; RAHAMAN, M. A. Service quality attributes affecting the satisfaction of railway passengers of selective route in southwestern part of Bangladesh. Theoretical and Empirical Researches in Urban Management, Bucharest, v. 4, n. 12, p. 115-125, Aug. 2009.

SAKELLARIOU, A. et al. Identification of quality indexes in school bus transportation system. Transportation Research Procedia, Amsterdam, v. 24, p. 212-219, 2017. https://doi.org/10.1016/j.trpro.2017.05.110

SANTOS, T. Transporte escolar rural na perspectiva de gestores e planejadores/operadores: subsídios para políticas públicas. Dissertação (Mestrado em Ciência Política) - Instituto de Ciência Política, Universidade de Brasília, Brasília, DF, 2010.

SCHUH, C.; LOPES, E. R.; FREITASG, V. C. Análise de viabilidade do transporte escolar em município da região central do Rio Grande do Sul. In: CONVENÇÃO DE CONTABILIDADE DO RIO GRANDE DO SUL, 15., 2015, Bento Gonçalves. Anais[...]. Porto Alegre: Academia de Ciências Contábeis do Rio Grande do Sul, 2015.

TRIBUNAL DE CONTAS DA UNIÃO - TCU. TCU verifica transporte escolar deficiente por todo o Brasil. Notícias TCU, June 1, 2020. Available from: https://portal.tcu.gov.br/imprensa/noticias/tcu-verifica-transporteescolar-deficiente-por-todo-o-brasil.htm. Access in: 2021 Mar. 31.

UNITED NATIONS - UN. Transforming our world: the 2030 agenda for sustainable development. New York, 2015. Available from: https://sustainabledevelopment.un.org/post2015/transformingourworld/. Access in: 2020 Jan. 22. 


\section{Information about the authors}

Maria Victória Leal de Almeida Nascimento: Doctor of Science in Civil Engineering at Universidade Federal de Pernambuco. Coordination for the Conselho de Aperfeiçoamento de Pessoal de Nível Superior. Contact: mvictorialan@gmail.com

iD https://orcid.org/0000-0003-4864-6292

Mauricio Oliveira de Andrade: Doctor of Science in Civil Engineering at Universidade Federal de Pernambuco. Conselho Nacional de Desenvolvimento Científico e Tecnológico Reseacher. Professor at Civil and Environmental Engineering Departament of Universidade Federal de Pernambuco. Contact: mauricio.andrade@ufpe.br

iD https://orcid.org/0000-0002-7377-7668 